\title{
USING INNOVATIVE DIGITAL SYNERGYTRON DEVICES TO SOLVE SOCIOECONOMIC PROBLEMS OF PROVIDING URBAN POPULATION WITH SAFE AND HIGH-QUALITY PLANT PRODUCTS
}

\author{
Bandurin Vladimir Vasilyevich \\ Vernik Peter Arkadyevich \\ Korshuk Vadim Alekseevich
}

Institute for Development Strategies, Moscow, Russia

The paper highlights the importance of innovative digital devices of the brand new, synergytron class, compatible with the sixth wave of innovation, for overcoming the socioeconomic problems of providing urban population with safe and high-quality plant products all the year around. In the world practice, protected on-the-ground systems are mainly used for year-round cultivation of crops. These systems exist in many variants, differing in the applied methods and technologies, design solutions, geometric characteristics, level of automation and dependence on human participation, as well as the number of other adjustable parameters. The paper considers the possibility of using the latest digital technologies for growing plants within urban environments taking into account the most advanced developments of the sixth wave of innovation. The paper also considers the influence of
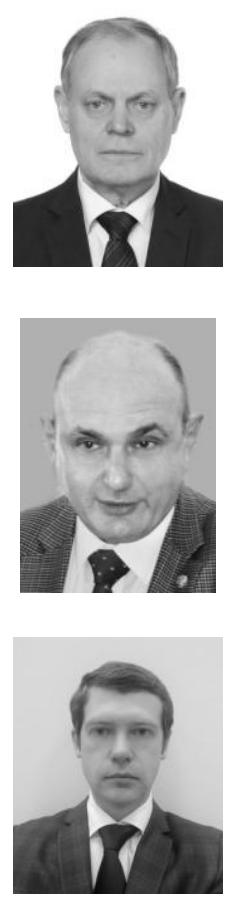

Bandurin Vladimir Vasilyevich

Doctor of Economics, Candidate of Science (Engineering), professor

Deputy Director for science, INPO “Institute for Development Strategies", Moscow, Russia.

Research interests: state antimonopoly policy, state financial control and audit, management of state property complex, foreign economic and international relations, digital technologies and innovations

Author of more than 220 scientific works, including 12 monographs

Email: vvband@mail.ru

Vernik Peter Arkadyevich

Director, INPO “Institute for Development Strategies", Moscow, Russia.

Research interests: socio-economic development of countries and regions, macroeconomics, mathematical modeling of nonlinear processes, interdisciplinary research, systems analysis, strategic management in hightech industries, scientific and technological development, methods of biological research, innovation, digital technology, legal regulation. Author of 15 scientific works

E-mail: vernik@isd.center

Korshuk Vadim Alekseevich

Department for economic analysis and modeling, Head of Department INPO "Institute for Development Strategies", Moscow, Russia.

Research interests: macroeconomics, mathematical modeling, innovation, digital technologies, legal regulation Author of 7 scientific works

E-mail: korshuk@isd.center 


\section{USING INNOVATIVE DIGITAL SYNERGYTRON DEVICES}

megatrends on the development of methods and systems for growing plants as well as evolution of the farming paradigm in general. The results obtained by the authors can be applied further to scientific and practical activities of both scientists and representatives of the business community.

Keywords: protected ground; closed systems; cloud computing; program management; crop production; cultivation system; synergytron; digitalization; digital devices; digital economy.

Rapid urbanization caused by the Earth's overall population growth makes the solution of the problem of providing urban population with safe and high-quality food products highly relevant today.

Urbanization, climate change, resource shortages have been identified by leading research organizations as the megatrends, shaping and predetermining long-term development of the world (PwC, 2015; EY, 2015; KPMG International, 2013).

According to the United Nations Organization, the world population will continue growing and by 2050 it is expected to exceed the number of 9.7 billion people. The process of urbanization is progressing accordingly. Thus, as of UN forecasts, by 2050 the share of urban residents worldwide is expected to reach $68 \%$ of the planet's population (United Nations, 2017, 2018). Such intensive growth of cities, in its turn, causes damages to sown areas, reducing their number, and according to the forecasts of the international team of scientists (Bren d'Amour et al., 2015), by 2030 expansion of urban settlements will result in the loss of at least $1.8-2.4 \%$ of the global sown areas.

Over the next 15-20 years, food demand will grow by at least 35\%. However, we already have planetary-scale problems with product supply. According to FAO (Food and Agriculture Organization of the United Nations) estimates, approximately one in nine people in the world suffer from malnutrition. The amount of hungry people is growing; back in 2017 alone their number was about 821 million people (FAO, 2018).

At the same time, agricultural production has been always the basis for formation of a healthy human diet (International Food Policy Research Institute, 2017), for this very reason, consumption of agricultural products is always on the increase, in parallel to the growth of world population.

Currently, consumer preferences are rapidly changing worldwide due growing popularity to healthier lifestyles and active longevity (European Parliamentary Research Service, 2016). Many European studies have shown that consumers of organic products prefer plant products in the first place, that is, vegetables, fruits, legumes and grains.

This intensively growing consumption cannot be satisfied through simple intensification of agricultural production (more fertilizers, extra means of protection against diseases and pests etc.) or through extensive ways of development (or in other words, through expansion of overall acreage). In the historical perspective, approaches to organization of agricultural production have changed greatly and evolved from primitive gathering to "digital cultivation" which is on the rise today.

According to the study performed by the consulting company "Delloitte", agriculture is transforming into a high-tech industry and this transformation is accelerated by ten global megatrends: growing world population, social and demographic changes, growing urbanization, climate change, smart agricultural technologies, biotechnology, service, integration of value chains, globalization of trade, change of international rules (Delloitte, 2016). 
Urban conditions, such as lack of acreage, special equipment, necessary competencies, insufficient insolation, polluted atmosphere, impose additional requirements for growing plant products within urban territories, Thus, the key features of agriculture development under urban conditions are: manufacturability, closeness, compactness, productivity, and energy efficiency.

However, economically, it is not feasible to solve the problem of providing urban population with safe and high-quality plant products by means of rhythmically daily delivery from nearby territories. Long-term storage of agricultural produce worsens its quality, destroys vitamins (Fedotova \& Blinova, 2012), and reduces its nutritional value. Besides, the price grows due to the cost of additional storage (since the seller has to pay extra for storage space, special facilities, extra chemistry, logistics, spoilage and unavoidable natural losses).

It should be noted that, according to FAO (2018), the largest loss of food produce comes from agricultural production, accounting for 33\%, of which 54\% comes from production, processing after harvesting and storage, and $46 \%$ - from processing, distribution and consumption.

That is why it is necessary to introduce innovations and apply the latest technologies for providing urban population with safe and high-quality plant products throughout the year. Cities need compact, highly productive, energy-efficient, software-controlled (so that to reduce human labour involvement in all processes) devices that, by means of creating optimal conditions for growth in a closed environment, will be able to produce plant products in close proximity to the places of consumption regardless of geographical location, season, weather and/or environmental conditions.

At present, the process of establishing farming within the limits of urban settlements is already well underway. Modern urban agriculture or urbanized agriculture is based on the introduction of devices that create a closed, controlled environment, partially operating in an automatic mode (Forecast of scientific and technological development of the agro-industrial complex of the Russian Federation for the period up to 2030, 2017). Such devices for urban cultivation of plant produce can be classified as follows (Rutkin et al., 2017): set-aside greenhouses, converted storage and production facilities, mobile systems based on standard containers, vertical farms, small-scale installations for home use and "grow boxes".

Key benefits and shortcomings of each class as well as their adoption as the basis for development of the system providing urban population with safe and high-quality plant products are considered herein. For example, small-scale installations for home use and the so-called "grow boxes" are now widely presented at the markets. The devices of this type are developed and manufactured locally in many countries, including Russia, USA, Israel, Japan, China etc. These installations for home use are mainly used for year-round cultivation of lettuce and other herbs (dill, parsley, green onion etc.), but they are not suitable for growing larger vegetable crops, berries or fruits.

As part of the ongoing research on the integrated solution to the food supply problem, the Russian organization INPO "Institute for Development Strategies" has created the device which we call "synergytron". According to its main characteristics, it can be attributed to a new class of closed-type digital devices for growing plants and conducting research in the field of crop production (Zelenkov \& Vernik, 2018). Synergytron is a closed-type digital device for cultivating biological objects basing on a software-controlled internal environment and a developed description language with feedback on moisture, composition of cultivation sources, temperature, lighting, acoustic effects, gas composition, air movement etc., 


\section{USING INNOVATIVE DIGITAL SYNERGYTRON DEVICES}

regardless of season and climatic conditions, and last but not least - with significant savings of all the related resources.

The principal novelty of synergytron is in combination of digital program based on management principles, the possibility of creating a program-controlled environment for growing plants, activation of the factors enhancing the biological potential of these plants, modularity and scalability. Together they make it possible to create installations of different scales - from small room installations to huge industrial plant-growing factories. Closed nature of this system makes it possible to most accurately regulate its microclimatic conditions.

Synergytron has no drawbacks typical of previous classes and types of plant-growing devices: human labor is totally excluded from the processes ensuring vegetation of plants; due to multi-tiered construction of this system, the space occupied is rationally, thus, it can be used inside residential blocks and also within other premises; energy efficiency is provided by using the latest technologies, optimal modes and algorithms. The principles laid down as fundamentals of the synergytron's functioning allow using it for year-round cultivation of all types of plant produce, including herbs, lettuce, vegetables, berries, fruits and other products necessary for a healthier diet of the contemporary city dwellers.

The synergytrons have been developed by the independent non-profit organization "Institute for Development Strategies", operated by scientists from leading scientific organizations of the Russian Federation. The data obtained during the experiments have confirmed the effectiveness of this design solution and of the principles laid down in synergytron for cultivation of plants. The results of the experiments have already been presented and explained in a number of already published research papers, thus, we have no intention to repeat them.

Agriculture has almost exhausted all possibilities for both intensive and extensive development, and as of today it is not even possible to predict the risks to global food security without a paradigm shift in its management. Global megatrends determine future directions in agricultural development and accelerate its transformation into a truly high-tech industry. Urbanization and innovative changes in food preferences impose additional requirements for food provision management and policies. In the ten-year perspective, traditional methods will become insufficient for meeting the growing urban demand for plant produce.

Cities will very soon need first additional and then alternative sources of fresh plant produce. Technologies today develop rapidly, preconditioning the continuous improvement of growing plants in greenhouses. Automated greenhouses, grow boxes, phytotrons, mobile agricultural farms, vertical farms and other similar inventions usually have relatively low technical level, are highly dependent on human labour, have the simplest program management and control by the minimum set of internal environment parameters. This makes it impossible to create an adequate model of the environment necessary for normal cultivation of specific plant species.

Unfortunately, nowadays outdated methods of open ground use are still the most popular and the most widely spread in plants' cultivation. Newer approaches to scientific research should be applied to use the newest and the most advanced capabilities of the most recent technologies so that to make the full use of the growing conditions management. 
The use of computer-controlled closed-type digital devices - or synergytrons, as we call them - seems to be the most promising novelty for the purposes of continuous, year-round provision of urban population with the safest and high-quality plant products.

\section{References:}

Bren d'Amour, C., Reitsma, F., Baiocchi, G., Barthel, S., Güneralp, B., Erb, K., Haberl, H., Creutzig, F. \& Seto, K. (2015). Future urban land expansion and implications for global croplands. Available at: https://www.pnas.org/content/pnas/114/34/8939.full.pdf

Delloitte. (2016). From Agriculture to AgTech: An industry transformed beyond molecules and chemicals. Available at: https://www2.deloitte.com/content/dam/Deloitte/ de/Documents/consumer-industrial-products/Deloitte-Tranformation-from-Agriculture-toAgTech-2016.pdf

European Parliamentary Research Service. (2016). Human health implications of organic food and organic agriculture. Available at: http://www.europarl.europa.eu/RegData/etudes/ STUD/2016/581922/EPRS_STU\%282016\%29581922_EN.pdf

EY. (2015). Megatrends 2015. Making sense of a world in motion. Available at: https://www.ey.com/Publication/vwLUAssets/ey-megatrends-report-2015/\%24FILE/eymegatrends-report-2015.pdf

FAO (2018). Food wastage footprint. Impacts on natural resources. Available at: http://www.fao.org/3/a-i3347e.pdf

FAO. (2018). The state of food security and nutrition in the world 2018. Available at:: http://www.fao.org/state-of-food-security-nutrition/en/

Fedotova, Z., Blinova, O. (2012). Safety and food hygiene. Samara, RIC SGCA.

Forecast of scientific and technological development of the agro-industrial complex of the Russian Federation for the period up to 2030. (2017). Available at: https://issek.hse.ru/data/2017/05/03/1171421726/Prognoz_APK_2030.pdf

International Food Policy Research Institute. (2017). Urban food systems for better diets, nutrition, and health. Available at: http://ebrary.ifpri.org/utils/getfile/collection/ p15738coll2/id/132925/filename/133137.pdf

KPMG International. (2013). Future State 2030: The global megatrends shaping governments. Available at: https://home.kpmg/be/en/home/insights/2013/10/what-are-the-globalmegatrends.html

PwC, (2015). Five Megatrends and Their Implications for Global Defense \& Security: Available at: https://www.pwc.com/ee/et/publications/pub/five-megatrends-implications.pdf

Rutkin, N., Lagutkina, L. \& Lagutkin, O. (2017). Urbanized agricultural production (city farming) as a promising direction for the development of global agricultural production and a way to improve the food security of cities. Vestnik of ASTU. Fishing Industry. 4.

United Nations. (2017). World Population Prospects: Data Booklet. Revision. Available at: https://esa.un.org/unpd/wpp/Publications/Files/WPP2017_DataBooklet.pdf

United Nations. (2018). World Urbanization Prospects: Revision. Available at: https://population.un.org/wup/Publications/Files/WUP2018-KeyFacts.pdf

Zelenkov, V., Vernik, P. (2018). Creation of closed agrobiotechnologies based on digital technologies - new opportunities for scientific knowledge of cell cultures and higher plants. Actual Biotechnology, 3 (26).

Paper submitted

Paper accepted for publishing

Paper published online
07 November 2018

12 January 2019

31 March 2019 